Ann. Biol. anim. Bioch. Biophys., 1979, 19 (3 A), 553-566.

\title{
Changes in the digestive microflora of holoxenic * rabbits from birth until adulthood
}

\author{
par Ph. GOUET, G. FONTY
}

Laboratoire de Microbiologie, I.N.R.A.,

Theix, Saint-Genès-Champanelle, 63110 Beaumont, France.

Summary. The total number of cultivable bacteria and the number of different bacterial groups were determined at 4 levels of the digestive tract. $i$. e. the stomach, small intestine, caecum and colon, in 34 holoxenic (conventional) rabbits between 2 and 56 days of age. The stomach of young rabbits was almost sterile during the first postnatal week, and bacteria were established very irregularly, depending on the individual. After weaning, the total number of bacteria tended to increase with age and stabilized between $10^{4}$ and $10^{6}$ bacteria/g content. The colonization of the small intestine was more rapid than that of the stomach and the microflora was more abundant. The range of individual variation was wide in the young but more reduced after weaning ; the microflora was stabilized between $10^{6}$ and $10^{8}$ bacteria/g intestine. The caecum and colon already harbored an abundant flora $\left(10^{7}\right.$ to $10^{9}$ bacteria $\left./ g\right)$ from the first week; the colony counts remained constantly high and varied little among samples. Rabbit microflora was characterized by the dominance of strictly anaerobic species, particularly non-sporulated Gram-negative bacilli (Bacteroides), distributed in the whole digestive tract. The number of sporulated anaerobic bacteria was 100 to 1000 times lower than that of Bacteroides, and they belonged to the genera Endosporus, Clostridium and Acuformis. The stomach almost never contained any Streptococci ; in the small intestine, caecum and colon their number reached a maximum in 7 to 14-day old rabbits $\left(10^{7}<1^{9}\right)$; it then regularly decreased with the age of the animals. After weaning, the Streptococci disappeared from the small intestine ; in the caecum and colon their number did not exceed $10^{4}$ bacteria/g. Young rabbits generally did not contain any enterobacteria ; they appeared later and reached a maximum at the end of week $3\left(10^{7} / \mathrm{g}\right)$, after which their number rapidly decreased. Enterobacteria were not regularly present after weaning. Micrococci were very seldom found, except in the stomach, and the rabbit digestive tract never harbored any Lactobacilli.

\section{Introduction.}

Digestive microflora have been studied in several animal species, including farm animals (pigs and chickens) and laboratory animals (rats and mice). Only a few investigations have been devoted to rabbits, although these animals are of great interest to the farmer as well as to the nutritionist and pathologist. The works of

* The terminology used is that of Raibaud et al. (1966c). 
Smith (1965 $a, b)$, Bornside and Cohn (1965) and Cohn and Bornside (1965) clearly reported that the composition of rabbit microflora was extremely original. This was confirmed by Govet and Fonty (1973) who showed the dominance of strictly anaerobic bacteria and the scarcity, or even absence, of the genera Lactobacillus, Streptococcus and Escherichia.

Before beginning to study host-digestive microflora interactions and the antagonisms or synergy within the flora, we needed a thorough knowledge of the different bacterial populations inhabiting the digestive trat, as well as their numerical fluctuations throughout the whole lifetime of the rabbit. In this report, therefore, we examined the evolution of the microflora at four different levels of the digestive tract in holoxenic rabbits from birth until adulthood.

\section{Material and methods.}

\section{A. Rearing conditions.}

We used rabbits of the New Zealand breed from our conventional laboratory colony. The microflora was studied in 34 rabbits, from 8 different litters, aged 2 to 56 days. One rabbit was removed from each of the first three litters on days $7,14,21$, 28, 42 and 56 after birth, and from litter 4 on days $2,3,7,14,21,28$ and 42 . Two rabbits were removed from litter 5 on days 3 and 42 and one rabbit from litter 6 on days 7, 14, 21, 42. Two 25-day old rabbits were taken from litters 7 and 8.

The young were born in concrete hutches on straw bedding or in a box next to it. From birth until weaning, they remained continuously with the dam and were nursed by her until day 16 when they were fed a supplementary diet including 10 p. 100 barley, 17 p. 100 oats, 14 p. 100 wheat, 7 p. 100 bran, 10 p. 100 horse bean, 5 p. 100 peanut meal, 5 p. 100 soyabeam meal, 25 p. 100 lucerne meal, 5 p. 100 yeast and 2 p. 100 mineral mixture until weaning on day 30 ; after weaning they were fed this dief ad libitum as a complete ration.

\section{B. Sampling and dilution of digesta.}

The microflora was studied in samples from four segments of the digestive tract : stomach, small intestine, caecum and colon. Before the samples were taken, the rabbits were killed with ether in the morning at the same hour. The adbomen was opened and the digestive tract fully unrolled in a sterile area. Either the whole or the half of the stomach was removed, depending on the size of the animals. The whole small intestine was taken until 21 days of age ; only the distal part (1/7 of the total length) of older rabbits was removed. The whole caecum and colon were excised from rabbits less than 21 days old, while only the median part of the caecum and proximal colon was used in older rabbits.

Each sample was immediately introduced into a 125 or $250 \mathrm{ml}$ flask and diluted 1 : 10 in a previously reduced dilution medium (MD I), according to Bryant and Burkey (1953) (table 1). After weighing, the sample was ground (without separating the container from its contents) with a Polytron apparatus using carbon dioxide gas (Hungate, 1966). 
Decimal dilutions were made in two different diluents according to the nature of the counting media, as shown in table 1. Using carbon dioxide gas, dilution medium 1 (MD I) was distributed into roll tubes in the proportion of $9 \mathrm{ml}$ per tube, and the dilutions were performed according to the same technique. In dilution medium II (MD II) (Raibaud et al., 1966a), all dilutions were carried out aerobically.

TABLE 1

Inoculation plan of the media and investigated microfloras

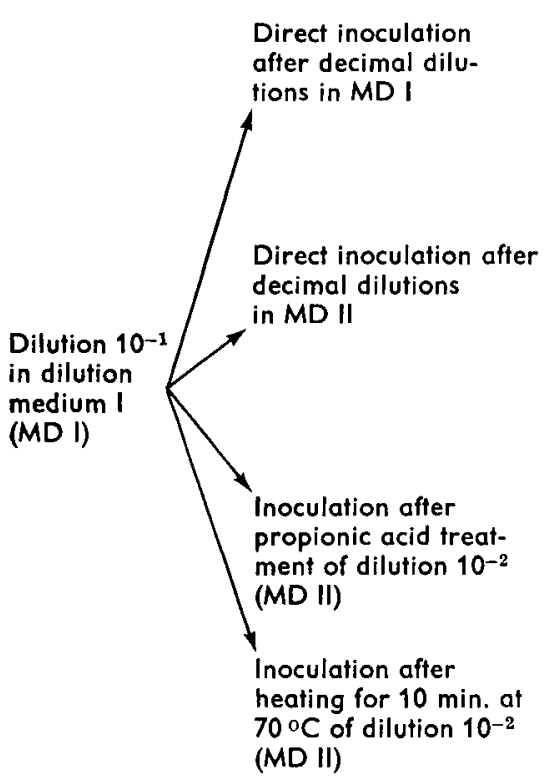

$\begin{array}{ll}\begin{array}{ll}\text { M10+++ } \\ \mathrm{A}^{+++} \\ \mathrm{B}^{++}\end{array} & \text {Total strictly anaerobic microflora } \\ \mathrm{TS}^{++} & \\ & \\ \mathrm{D}^{++} & \text {Total strictly anaerobic microflora } \\ \mathrm{G1}^{++} & \\ \mathrm{C}^{+} & \text {Total facultative anaerobic microflora } \\ \mathrm{DCA}^{+} & \text {Enterobacteria } \\ \mathrm{AGAT}^{+} & \text {Streptococcus } \\ \text { TSN } & \text { Sulfito-reducing Clostridium } \\ \mathrm{Rogosa}^{++} & \begin{array}{l}\text { Lactobocillus } \\ \text { MRS }\end{array} \\ \mathrm{H}^{++} & \text {Lactobacillus } \\ \mathrm{J1}^{+} & \text {Micrococcus } \\ & \text { Staphylococcus }\end{array}$

Ap ${ }^{++} \quad$ Propionic acid-resistant strict anaerobes

$\mathrm{K}^{\prime} \mathrm{T}^{++} \quad$ Sporulated ancerobic microflora

$\mathbf{B}^{\prime++}$

$t=$ Petri dishes

$++=8 \times 400 \mathrm{~mm}$ tubes

$-++=$ Hungate's roll fubes

C. Counting media.

The different culture media used and the bacterial genera or groups investigated in these media are shown in table 1 . The total number of aerobically cultivable bacteria was estimated in medium C (Raibaud et al. ,1966a) and the total number of anaerobically cultivable bacteria in media $M 10$ (Caldwell and Bryant, 1966), A', B' (Raibaud ef al., 1974) and TS. The latter corresponded to medium $E$ of Raibaud ef al. (1966a) admixed with 1 p. 100 yeast autolysate.

The enterobacteria were enumerated on deoxycholate agar medium (DCA) (Difco), Streptococcus on medium AGAT of Raibaud et al. (1961), and Lactobacillus on media Rogosa (Difco) and MRS (Difco).

Micrococcus was counted on medium H 1 of Raibaud et al. (1966a) and Staphylococcus on medium J 1 of Dickinson et al. (1968). We tried to determined the latter in only 
4 rabbits aged 7, 14, 25 and 42 days, respectively. The number of Clostridium was estimated in media TSN (Bio-Merieux), D 1 and G 1 (Raibaud et al., 1966a), and the number of spores in media $B^{\prime}$ and $K^{\prime} T$ of Raibaud ef al. (1974); the inoculum of the latter medium was composed of the decimal dilutions of sample $10^{-1}$ heated for $10 \mathrm{~min}$. at $70^{\circ} \mathrm{C}$.

Before inoculating media $H 1, J 1, D 1, A G A T$ and $A p$, the inocula were treated by incubating the microorganisms of $1 \mathrm{ml}$ dilution in sterile $18 \times 180 \mathrm{~mm}$ tubes in the presence of inhibitors for $5 \mathrm{~min}$. at $37^{\circ} \mathrm{C}$ (Raibaud et al., 1966a).

Media $M 10, A, B^{\prime}$ were inoculated from MD 1 ; the others from MD II, media $C$, DCA, AGAT, H 1, J 1, TSN, Rogosa and MRS were pour-plated in Petri dishes and incubated aerobically, except for medium TSN which was incubated anaerobically in jars using the Gaspak system of BBL.

Reduced media $\mathrm{M} 10$ and $A$ were inoculated anaerobically under $\mathrm{CO}_{2}$ in two roll tubes for each dilution according to Hungate's technique (1966). The other media, regenerated $20 \mathrm{~min}$. in boiling bath, were inoculated anaerobically in $8 \times 400$ tubes (Raibaud et al., 1966a).

All media were incubated at $37^{\circ} \mathrm{C}$. The media in Petri dishes were incubated for $48 \mathrm{hrs}$., the others for 7 days.

\section{Presumptive identification of isolated strains.}

The colonies isolated from the roll tubes or from the $8 \times 400 \mathrm{~mm}$ tubes were subcultured in media $A$ or $B^{\prime}$ in Veillon's tubes. The colonies isolated from the Petri dishes were subculturel aerobically in medium $A$, except for the enterobacteria, which were subculturel on trypticase-soybean agar (Difco).

After purification, we determined the genera of about 1500 isolated strains under phase-contrast by observing the morphology, motility and presence of spores in fresh cultures after $18 \mathrm{hrs}$. of growth or, in some cases, after several days. The presence of spores was confirmed for some strains by heating $1 \mathrm{ml}$ of 18-hour broth culture for $10 \mathrm{~min}$. at $75^{\circ} \mathrm{C}$, followed by subculture on agar containing medium $\mathrm{A}$ in Veillon's tubes. The Gram-straining technique of Holdeman and Moore (1972) was applied to the cultures during early growth. We tried to determine if catalase was present ; the respiratory type was defined by inoculating media $A$ or $B^{\prime}$ with the strains isolated in Veillon's tubes.

\section{Results.}

All counts were expressed per gram of fresh samples and each point on each figure corresponds to the count made in one animal.

Effect of aerobic or anaerobic dilution technique on the total number of bacteria obtained after anaerobic incubation in $8 \times 400 \mathrm{~mm}$ tubes.

Table 2 shows that in two samples of caecal contents and in one of colonic content, the number of bacteria obtained in medium $B^{\prime}$ was 15 to 24 times greater when dilu- 
fions were made anaerobically with Hungate's technique than when they were made aerobically.

TABLE 2

Influence of dilution technique on total number

of bacteria obtained ofter anaerobic incubation in $8 \times 400 \mathrm{~mm}$ tubes

\begin{tabular}{cccc}
\hline & \multicolumn{3}{c}{ Dilution technique } \\
\cline { 2 - 4 } Organ & $\begin{array}{c}\text { Anaerobic } \\
\text { dilutions } \\
\text { (a) MD I }\end{array}$ & $\begin{array}{l}\text { Aerobic } \\
\text { dilutions } \\
\text { (b) MD II }\end{array}$ & Ratio $\frac{(\text { a) }}{(b)}$ \\
\hline Caecum $1 \ldots \ldots \ldots \ldots$ & $1,2 \times 10^{10}$ & $7 \times 10^{8}$ & 19 \\
Caecum $2 \ldots \ldots \ldots \ldots$ & $4,8 \times 10^{8}$ & $2 \times 10^{7}$ & 24 \\
Côlon $\ldots \ldots \ldots \ldots \ldots$ & $1,5 \times 10^{8}$ & $1 \times 10^{7}$ & 15 \\
\hline
\end{tabular}

Anaerobic and aerobic bacterial counts.

Figure 1 clearly shows that the strictly anaerobic microflora was dominant in almost all samples, whatever the segment of the digestive tract studied and whatever the age of the animals.
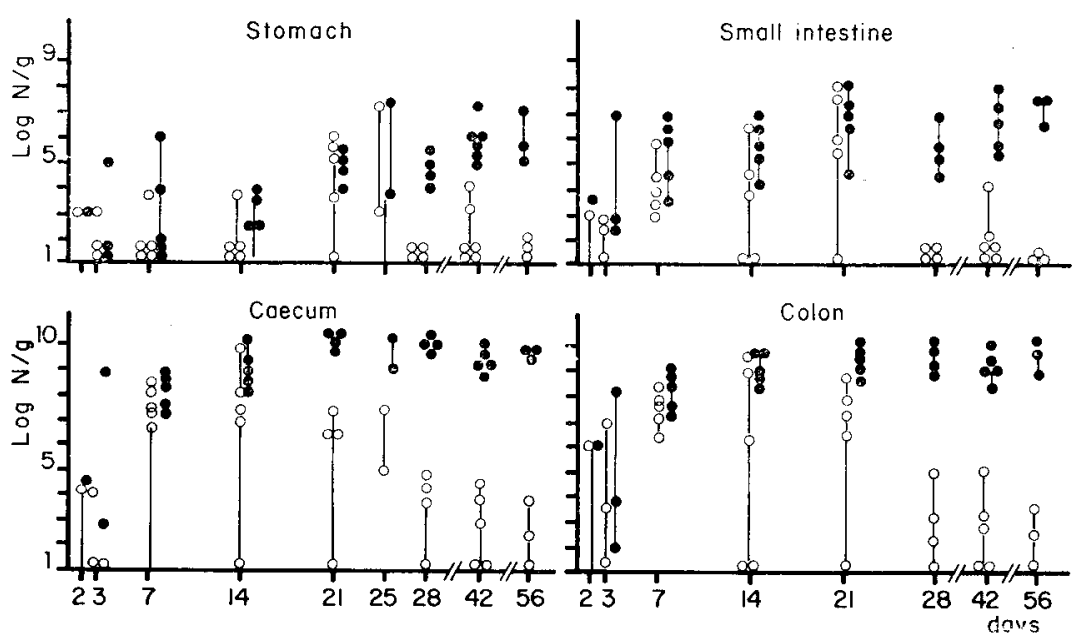

FIG. 1. - Changes in total numbers of aerobic ( 0 ) and anaerobic ( $\bullet$ ) bacteria accordind to rabbit age.

In the stomach, the establishment of facultative anaerobes and strict anaerobes was slow, irregular and varied widely from animal to another. During the first 2 weeks, 6 young rabbits out of the 8 studied harbored no microflora in the stomach, and the number of bacteria found in 6 others did not exceed $10^{4} / \mathrm{g}$ content. Only 2 rabbits exhibited a relatively high colony count $\left(10^{5}\right.$ to $\left.10^{6} / \mathrm{g}\right)$ based on strict anae- 
robes. From day 21, a microflora was constantly present and the number of anaerobes substantially increased with age. Variations between individuals were less marked after weaning at day 30 , but they nevertheless remained wide and sometimes differed by a factor of 1000 .

The bacterial colonization of the small intestine was more rapid than that of the stomach. Although the microflora was small in most cases, it was always found during the first postnatal week ; individual variations were also very large, particularly in young rabbits. On an average, the bacterial population increased up to day 7 . The colony counts were always 10 to 100 -fold higher than those of the stomach. The proportion of facultative anaerobes was sometimes a little higher before weaning, while in weaned rabbits the microflora very often did not contain any.

In the caecum of 2 to 3-day old rabbits (fig. 1), the total number of bacteria varied considerably, according to the sample, and the number of facultative anaerobes sometimes reached that of the anaerobes. At the end of the first week, the caecum habored an abundant flora ( $10^{7}$ to $10^{9}$ bacteria $/ g$ ) with slightly subdominant facultative anaerobes. From week 2 , the colony counts were even higher $\left(10^{9}\right.$ to $\left.10^{10} / \mathrm{g}\right)$ with only slight variations, depending on the sample and on animal age. From that time, the number of facultative anaerobes tended to drop sharply $\left(10^{2}\right.$ to $\left.10^{4} / \mathrm{g}\right)$ or even disappear in some samples after weaning.

The evolution of colonic microflora (fig. 1) was the same as that of the caecum. Numerations at 42 days showed that the colony counts were slightly and systematically lower in the colon than in the caecum (table 3).

\section{TABLE 3}

Comparison of the numbers $(\log 10)$ of strictly anaerobic bacteria obtained on medium $A$ per $g$ of caecal and colonic contents in 6 rabbits aged 42 days

\begin{tabular}{ccccccc}
\hline Rabbit $n^{\circ}$ & 1 & 2 & 3 & 4 & 5 & 6 \\
\hline Caecum............ & 9,5 & 9,3 & 9,1 & 9,3 & 8,8 & 9,1 \\
Colon $\ldots \ldots \ldots \ldots$ & 9,3 & 9,1 & 8,9 & 9,1 & 8,6 & 8,9 \\
\hline
\end{tabular}

The facultative anaerobic microflora was exclusively composed of enterobacteria and streptococci (fig. 2). The enterobacteria were not established during the first 2 postnatal weeks, as they were not found in any organ of 12 of the 14 rabbits 2 weeks old or less. In addition, they were only observed in large numbers in the small intestine of only 1 animal at 14 days of age. But, in nearly all cases, at 21 and 25 days the enterobacteria represented one of the dominant groups of the total bacterial flora of those organs. From week 4, they disappeared from the stomach of the weaned rabbits and were very seldom observed in the small intestine. The numbers of enterobacteria in the caecum and colon were 10 to 100 -fold higher than in the small intestine, but their distribution according to age was almost the same, maximum values once again being reached between weeks 1 and 3 . However, the enterobacteria population was 100 to 
1000 times smaller than any of the other bacterial populations of the microflora. From 28 to 56 days, no enterobacteria were observed in the digestive tract of 7 rabbits out of 13.

The Streptococci appeared earlier than the enterobacteria, and from day 7 almost all rabbits contained some, except in the stomach. Only 4 animals out of the 34 studied harbored these bacteria in that organ and their number did not exceed $1000 / \mathrm{g}$ (fig. 2). In the small intestine, the caecum and the colon, streptococci were established at

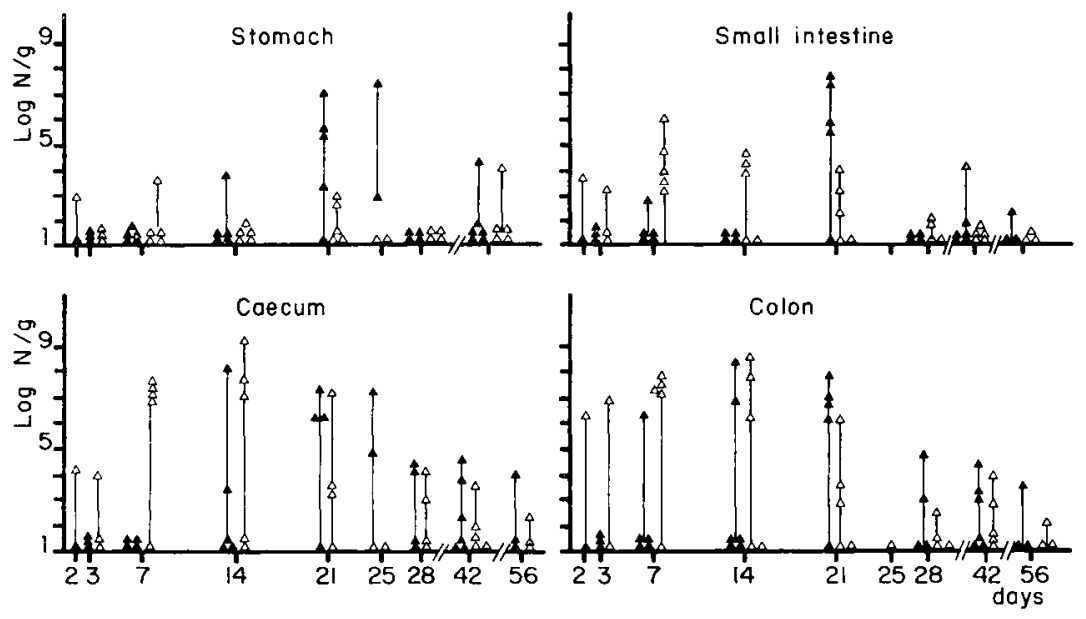

FIG. 2. - Changes in numbers of enterobacteria ( $\Delta$ ) and streptococci $(\Delta)$ according to rabbit age.

the end of the first week. At that time, they constituted the overall facultative anaerobic microflora and represented one of the largest bacterial groups; only 1 rabbit did not harbor any in either the caecum or the colon. In 3 out of 5 cases, the number of Streptococci on day 14 was still the same as that of the dominant microflora $\left(10^{3}\right.$ to $10^{5} / \mathrm{g}$ in the small intestine, $10^{7}$ to $10^{9} / \mathrm{g}$ in the caecum and colon). Thereafter, their number decreased with age, and at 21 days they were less numerous than the enterobacteria. In weaned rabbits, streptococci were almost absent in the small intestine and were present in very irregular, small numbers in the caecum and colon $\left(10^{2}\right.$ to $\left.10^{4} / \mathrm{g}\right)$.

Five out of 20 rabbits aged 21 days or more did not harbor either enterobacteria or streptococci at any level of the digestive tract, 4 contained streptococci but no enterobacteria, and 2 contained enterobacteria but no streptococci.

Micrococci were only found when their number was sufficiently high or when the streptococci were absent. As a matter of fact, the streptococci selectively enumerated on medium AGAT also grew on the so-called selective medium of the micrococci. From the dominant flora, we isolated facultative anaerobic Gram-positive cocci, possessing a catalase, which we classified among the micrococci. They were rarely present, except in the stomach. In that organ, the following colony counts were obtained in 8 rabbits : $2 \times 10^{3} / \mathrm{g}$ in one 3-day old animal, $10^{3} / \mathrm{g}$ in one of 14 days, $10^{4} / \mathrm{g}$ in one of 21 days, $10^{4}$ and $10^{5} / \mathrm{g}$ in fwo of 28 days, $2 \times 10^{4}$ and $10^{5} / \mathrm{g}$ in two of 42 days 
and $10^{4} / \mathrm{g}$ in one of 56 days. These bacteria were present in the small intestine of 4 rabbits 3 days $\left(8 \times 10^{2} / \mathrm{g}\right), 42$ days $\left(10^{4}\right.$ and $\left.10^{5} / \mathrm{g}\right)$, and 56 days $\left(10^{5} / \mathrm{g}\right)$ old. Some were found in the caecum and colon of 2 weaned rabbits $\left(10^{6}\right.$ and $\left.10^{7} / \mathrm{g}\right)$.

No staphylococci were isolated from medium J 1 in 4 rabbits 4, 14, 25 and 42 days old, respectively.

No lactobacilli were found in the media used, whatever the level of the digestive tract of the age of the rabbits.

\section{Enumeration of strictly anaerobic bacteria.}

Enumeration of sporulated strictly anaerobic bacteria. In rabbits from the first 3 litters, we only counted the sulfito-reducing Clostridium in medium TSN. In rabbits from the following litters, the number of sporulated strictly anaerobic bacteria was estimated by comparing counts on the heated medium $B^{\prime}\left(B^{\prime} c\right)$ and on media $D 1$ and G 1.

Figure 3 shows the results obtained at the different levels of the digestive tract. Sulfito-reducing Clostridium bacteria were not established in either the stomach or the small intestine, and were only sporadically found at the time of weaning. They were also absent in the caecum and colon during the first 4 weeks, but at the time of weaning at 28 days, their number might reach $10^{5}$ to $10^{6} / \mathrm{g}$. Thereafter, it tended to regress $\left(10^{4} / \mathrm{g}\right)$ at the age of 42 to 56 days; one rabbit did not contain any at 56 days.

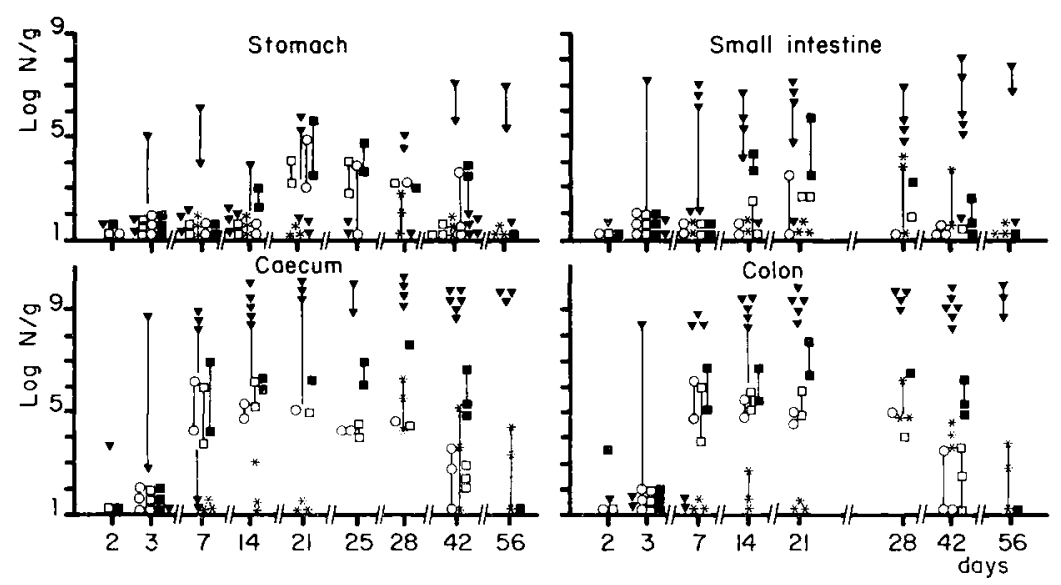

FIG. 3. - Changes in numbers of non-sporulated (A) and sporulated anaerobic bacteria (B'c medium $\square$, Ap medium o, TSN medium for sulfito reducing Clostridium $*$, D1 medium $\bullet$ ) according to rabbit age.

Sporulated anaerobic bacteria enumerated in D 1 and $G 1$ were absent in the caecum and colon of 2 or 3-day old tabbits : they then reached $10^{5}$ to $10^{7} / \mathrm{g}$ from day 7 and remained stable. From days 7 to 21, the dominant genera of this sporulated flora were Endosporus, except in the colon of a 7-day old rabbit in which Acuformis was found. On the other hand, Acuformis exhibited the highest colony counts in rabbits aged 25 to 42 days. According the figure 3, there was a rather good similitude between the evolution of the colonies counted after heating on $B^{\prime}$ and that of the colonies 
counted on Ap. These two floras remained grouped and similar to that enumerated on $D 1$ until day 14, but beyond that period, the latter stabilized or slightly increased, whereas flora $B^{\prime}$ or $A p$ decreased until day 42 . The ratio established between colony counts on $B^{\prime} c$ and those obtained on $D^{1}$ (spores and some vegetative cells) $\times 100$ (fig. 4) ranged between 2 and 100 p. 100 in the caecum and colon of rabbits less than 3 weeks old, whereas it was 100, or even 1000 , times lower in rabbits more than 25 days old. As compared with the counts obtained on D 1, the proportion of (sporulated) propionic acid-resistant bacteria decreased with the age of the animals. In the former case as in the latter, the decrease recorded from the third week corresponded to the period of establishment of Gram-positive sporulated bacteria of the genus Acuformis.

This indicated that the proportion of spores formed by Acuformis in the caecum and the colon of rabbits was lower than that of Endosporus and that the vegetative cells of Acuformis were more sensitive to propionic acid.

Enumeration of non-sporulated strictly anaerobic bacteria. These bacteria were counted (fig. 4) after examination of the colonies developed in media A, M 10,W at the highest sample dilutions; no qualitative difference was observed between the various strains in these three media.

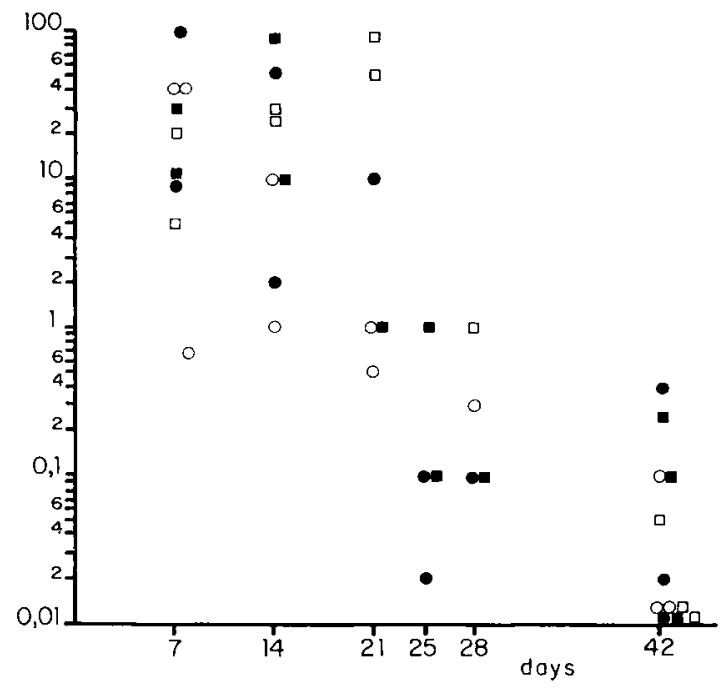

FIG. 4. - Changes in rate $\frac{\text { Number of spores on Ap or B'c medium }}{\text { Number of colonies on D1 medium }} \times 100$

in the caecum and the colon (each point is a sample) according to rabbit age.

- Caecum $\left\{\begin{array}{ll}\text { Ap medium } & \circ \text { Caecum } \\ & \text { a Côlon }\end{array}\right\} B^{\prime}$ c medium

All the non-sporulated Gram-negative strictly anaerobic bacteria isolated were very pleomorphic bacilli with slender or rounded ends, exhibiting swellings and spheroid or filamentous shapes. These bacilli belonged to the Bacteroidaceae, but with the fests 
used we could not more accurately identify their genera (Bacteroides, Fusobacterium or Sphaerophorus). These bacteria were seldom found in the stomach before weaning at day 30 , whereas in adult rabbits they were more regularly present and, in many cases, constituted the main component of the microflora of that organ. They were established more rapidly in the small intestine, the caecum and the colon than in the stomach and, according to the sample, during the first or second week after birth. Apart from some samples from the small intestine, these bacteria were always present after that in the dominant microflora, being the most stable and the largest population of the three organs.

The morphology of non-sporulated Gram-positive bacteria was close to that of Corynebacteriaceae (bacilli often arranged in the shape of $a \mathrm{~V}$, in palisades or in heaps), since the former were only irregularly round in the stomach and in the small intestine. They were present in the stomach of 6 rabbits : one at the age of 13 days $\left(5.10^{3} / \mathrm{g}\right)$, one at 28 days $\left(10^{4} / \mathrm{g}\right)$, three at 42 days $\left(9.10^{5}, 8.10^{5}, 7.10^{5} / \mathrm{g}\right)$ and one at 56 days $\left(4.10^{5} / \mathrm{g}\right)$. In the small intestine the following colony counts were obtained in 3 rabbits : one at 21 days $\left(2.10^{5} / \mathrm{g}\right)$, one at 42 days $\left(1.10^{5} / \mathrm{g}\right)$ and one at 56 days $\left(4.10^{7} / \mathrm{g}\right)$.

\section{Discussion.}

The numerical results were always underestimated since the content analyzed frequently included part of the intestinal membrane. The content/intestinal membrane ratio varied according to the organ studied, but the number of bacteria at the different levels varied in much larger proportions. We reduced that proportion by killing the animals at the same time intervals after the meals.

The number of bacteria, which was 15 to 25 -fold higher when the sample was diluted anaerobically rather than aerobically, clearly emphasizes the importance of using anaerobic dilution techniques for rabbit digestive microflora in which the most numerous bacteria are very oxygen-sensitive. However, the results of our colony counts in the caecum and the colon were 100 to 1000 times lower than those of Bonnafous and Raynaud (1968) who recorded a $1.4 \times 10^{12}$ bacteria/g content. This difference cannot be explained solely by the fact that the microscope counting techniques used by those authors always gave higher values. Despite the imperfection of the culture techniques of those anaerobes, it would seem quite unlikely that our colony counts would only be $1 / 100$, or even $1 / 1000$, of theirs.

The selectivity of the media used for counts of strict anaerobes is still insufficient. As these anaerobes also grow on D 1 and $G 1$, it is difficult to distinguish between sporulated anaerobic bacteria and streptococci when the latter are numerous. Thus, observation of the colonies on the various media is a prerequisite for a more accuate determination of their numbers. In some cases, the number of sporulated bacteria can also be estimated on medium Ap where most streptococci are inhibited, but the colony counts are always lower than those obtained on media D 1 and G 1 .

The quality and selectivity of the media used for counting the streptococci and enterobacteria are now almost perfect, and the numbers found truly reflect the in situ presence of these two groups constituting the overall facultative anaerobic microflora of rabbits. 
The first characteristic of young rabbit microflora was the very irregular establishment of bacteria in the digestive tract. During the first 3 days after birth, no microflora, or an extremely reduced one, was found, and a large population was observed in the caecum and the colon only after 1 week. These results are in keeping with those of Smith (1965a) who did not isolate any bacteria in rabbits less than 4 days old and with those of Ducluzeau et al. (1975) concerning the microflora of young hare and doe-hare. However, they contrast with the results of Lev and Briggs (1956a, b) and Smith (1965a) in rats and chickens exhibiting an abundant microflora in the digestive tract after ingestion of the first meal.

The microflora was scanty, or even absent, during the first 3 weeks after birth, especially in the stomach, despite the presence of an only slightly acid $\mathrm{pH}$ range $(4.5$ to 5). This phenomenon was undoubtedly related to the existence of an anti-bacterial factor in rabbit milk, identified by Canas-Rodriguez and Smith (1966) as octanoic and decanoic acids constituting 65 p. 100 of the total fat content. This «sterilizing 》 factor in the stomach obviously contributed to filtering and retarding the establishment of a digestive flora which was only permanently present in the stomach when the young began to eat a feed supplement from day 17. Towards weaning at day 30 , coprophagy began, and the bacteria present in the stomach (mainly strict anaerobes belonging to the same genera as those of the caecum, Ducluzeau et al., 1975), probably were a result of a recycling of the bacterial flora of the caecotrophes. Rabbits whose caecotrophy is hindered always have a sterile stomach (Smith, 1965a). If should be noted that most of the reingested bacteria were rapidly destroyed, as their number was 10 to 100000 times lower than in the feces. Thus, the rabbit stomach is not colonized by a caecal microflora during transit. Its important role in the feeding of rabbits, especially protein feeding, has been well established, but its active role in the digestive processes has not yet been demonstrated owing to the small number of living cells.

The colonization of the small intestine, the caecum and the colon was more rapid than that of the stomach and the colony counts recorded were much higher. At that level of the digestive tract where the stomachal anti-bacterial factor had been absorbed or metabolized, an autochtonous microflora seemed to be rapidly established, but the number of bacteria was always 100 to 1000 times higher in the distal parts of the digestive tract than in the small intestine. The number of bacteria also systematically decreased from the caecal to the colonic contents, a fact confirming the observations of Bonnafous and Raynaud (1969), and perhaps the existence of a «lysis factor 》 in the colonic fluid.

The second characteristic of the digestive microflora of young rabbits was that the facultative anaerobic microflora had a very simple composition. It was dominated by streptococci, until day 14 while enterobacteria were seen occasionally. Lactobacilli were never found. The progressive change in feeding leading to weaning caused a reduction in the number of streptococci and the appearance of enterobacteria, but it could not be affirmed that only diet plays a part in the kinetics of microflora establishment. As a matter of fact, the absorptive properties of the digestive tract change with age ; a large number of gut enzymes are triggered (Henschel, 1973 ; Lebas et al., 1971) and may act upon the nutrients. The modifications observed among the sporulated anaerobic bacteria most certainly also play a part that are unable to be accurately 
defined at the present time. In any case, Olfert ef al. (1976) have shown that the facultafive anaerobic population is highly subdominant and even absent in healthy adults. In the case of intestinal affections, we observed, as did Vörös (1976), E. coli counts in the caecum reaching $10^{9}$ or even more ; these bacteria belonged to various serotypes (Yalcin and Cordier, 1976 ; Renault et al., 1976).

The marked predominance of non-sporulated strictly anaerobic bacteria in the small intestine, caecum and colon of all young rabbits was the third characteristic of the intestinal microflora studied. Contrary to Ducluzeau et al. (1975) and Trovatelli et al. (1974), we did not find any Bifidobacterium, but only Gram-negative bacteria. These bacteria, together with an equivalent number of facultative anaerobic streptococci, were established very early in the rabbit digestive tract. In most cases, they constituted the dominant flora of the intestine from day 7, whereas in other mammals they only appear at the time of weaning (Fuller and Lev, 1964 ; Lee et al., 1971 ; Raibaud et al., 1966b). These findings confirm those of Smith $(1965 a, b)$ and Bornside and Cohn (1965), but those authors did not show the presence of sporulated anaerobic bacteria. According to our results, it seems that Endosporus before weaning and Acuformis afterwards, together with Bacteroides, constitute the dominant microflora in the caecum and colon of rabbits. The results reported in figures 3 and 4 clearly show that profound changes may take place from birth to adulthood. Are these changes related only to the progressive replacement of Endosporus by Acuformis or to modifications of the host physiology as affected by an environmental pressure? These questions cannot be answered, but it is clear that only sporulated and non-sporulated strictly anaerobic bacteria constitute the « autochtonous microflora » of rabbits, as defined by Dubos ef al. (1965).

Reçu en avril 1978.

Accepté en novembre 1978.

Résumé. La composition et l'évolution de la microflore digestive du Lapin holoxénique ont été étudiées aux niveaux de l'estomac, de l'intestin grêle, du caecum et du côlon chez 34 lapereaux âgés de 2 à 56 jours et allaités par leur mère avant sevrage. L'analyse différentielle quantitative a été effectuée à partir de 14 milieux de culture et en utilisant la technique de Hungate pour la recherche des bactéries anaérobies strictes.

La vitesse de colonisation de l'estomac varie beaucoup selon les individus; le nombre total de bactéries est généralement faible mais tend à augmenter avec l'âge et il se stabilise après sevrage entre $10^{4}$ et $10^{6}$ bactéries par gramme.

Dans l'intestin grêle l'implantation des bactéries est plus rapide et plus abondante que dans l'estomac; l'amplitude des variations individuelles, importante chez les jeunes lapereaux, s'estompe après sevrage et la microflore se stabilise entre $10^{6}$ et $10^{8}$ par gramme.

Le caecum et le côlon hébergent dès la première semaine une flore abondante ( $10^{7}-19^{9}$ bactéries/gramme) ef par la suite le nombre de bactéries reste constamment élevé, variant peu suivant les échantillons.

Au plan qualitatif la microflore du Lapin se caractérise par la dominance d'espèces anaérobies strictes et particulièrement de bacilles Gram négatifs (Bacteroïdes) que l'on retrouve à tous les niveaux du tube digestif. Les bactéries anaérobies sporulées sont de cent à mille fois moins nombreuses que les Bactéroïdes et appartiennent aux genres Clostridium, Endosporus et Acuformis.

Les Streptocoques (Str. faecalis et Str. faecium) sont presque toujours absents de l'estomac. Dans l'intestin grêle, le caecum et le côlon leur nombre atteint son maximum chez les lapereaux âgés de 7 à 14 jours el diminue régulièrement avec l'âge. 
E. coli est en général absent chez les jeunes lapereaux. Cette espèce apparaît ef atteint un maximam $\left(10^{7} / \mathrm{g}\right)$ à la fin de la troisième semaine puis diminue rapidement.

La période de sevrage se caractérise par une augmentation sensible d'E. coli et des streptocoques qui régressent ensuite rapidement.

Enfin l'absence générale de Lactobacillus dans le tube digestif du Lapin fait de cet animal une notable exception parmi les rongeurs dont la microflore a été étudiée.

\section{References}

BONNAFOUS R., RAYNAUD P., 1968. Mise en évidence d'une activité lysante du côlon proximal sur les micro-organismes du tube digestif du lapin. Arch. Sci. physiol., 22, 57-64.

BONNAFOUS R., RAYNAUD, 1969. Etude électrophorétique sur gel de polyacrilamide du suc cholique de lapin. Recherche d'un facteur lysant. C. R. Acad. Sci. Paris, Sér. D, 269, 1004-1006.

BORNSIDE G. H., COHN I. H., 1965. The normal microbial flora. Comparative bacterial flora of animals and man. Amer. J. Dig. Dis., 10, 844-852.

BRYANT M. P., BURKEY L. A., 1953. Cultural methods and some characteristics of some of the more numerous groups of bacteria in the bovine rumen. J. Dairy Sci., 36, 205-217.

CALDWELL D., BRYANT M. P., 1966. Medium without rumen fluid for non selective enumeration and isolation of rumen bacteria. Appl. Microbiol., 14, 794-801.

CANAS-RODRIGUEZ A., SMITH H. W., 1966. The identification of the antimicrobial factors of the stomach content of suckling rabbits. Bioch. J., 10, 79-82.

COHN I. H., BORNSIDE G. A., 1965. Imbalance of the normal microbial flora. Influence of strangulation obstruction upon the bacterial ecology of the small intestine. Amer. J. Dig. Dis., 10, 873-882.

DICKINSON A. B., RAIBAUD P., MOCQUOT G., 1968. Agar medium for the selective enumeration of coagulase positive Staphylococcus from the rat alimentary tract. J. Bacteriol., 95, 418-425.

DUBOS R., SCHAEDLER R. W., COSTELLO R., HOET P., 1965 . Indigenous, normal and autochtonous flora of the gastro-intestinal tract. J. exp. Med., 122, 67-76.

DUCLUZEAU R., DUBOS F., MARTINET L., RAIBAUD P., 1975. Digestive tract microflora in healthy and diarrheic young hares born in capacity. Effect of intake of different antibiotics. Ann. Biol. anim. Bioch. Biophys., 15, 529-539.

FULLER R., LEV M., 1964. Quantitative studies on some of the Gram negative anaerobic bacterıa in the pig alimentary tract. J. appl. Bact., 27, 434-438.

GOUET Ph., FONTY G., 1973. Evolution de la microflore digestive du lapin holoxénique de la naissance au sevrage. Ann. Biol. anim. Bioch. Biophys., 13, 733-734.

HENSCHEL M. J., 1973. Comparison of the development of proteolytic activity in the abomasum of the preruminant calf with that in the stomach of the young rabbit and guinea-pig. Brit. $J$. Nutr., 30, 285-296.

HOLDEMAN L. V., MOORE W. E. C., 1972. Anaerobe laboratory manual. Virginia Polytechnic Institute (U.S.A.).

HUNGATE R. E., 1966. A roll tube method for cultivation of strict anaerobes. Methods in microbiology. Acad. Press, New York and London, 3 B, 117-132.

LEBAS F., CORRING T., COURTOT D., 1971. Equipement enzymatique du pancréas exocrine chez le lapin, mise en place et évolution de la naissance au sevrage. Relation avec la composition du régime alimentaire. Ann. Biol. anim. Bioch. Biophys., 11, 399-413.

LEE A., GORDON J., LEE C. J., DUBOS R., 1971. The mouse intestinal microflora with emphasis on the strict anaerobes. J. exp. Med., 133, 339-352.

LEV M., BRIGGS A. E., 1956a. The gut flora of the chick. I. - The flora of newly hatches chicks. J. appl. Bact., 19, 36-38.

LEV M., BRIGGS A. E., 1956b. The gut flora of the chick. II. - The establishment of the flora. J. appl. Boct., 19, 224-230.

OL.FERT E. D., ROL W. E., JONES G. A., 1976. Observations on the microecology of the rabbit gastro intestinal tract. 1 er Congr. int. Cunic., Dijon, France, Communic. $n^{\circ} 35$. 
RAIBAUD P., CAULET P., GALPIN J. V., MOCQUOT G., 1961. Studies on the bacterial flora of the alimentary tract of pigs. II. - Streptococci : selective enumeration and differenciation of the dominant group. J. appl. Bact., 24, 285-306.

RAIBAUD P., DICKINSON A., SACQUET E., CHARLIER H., MOCQUOT G., 1966a. La microflore du fube digestif du rat. I. - Techniques d'étude et milieux de culture proposés. Ann. Inst. Pasteur, 110, 568-590.

RAIBAUD P., DICKINSON A., SACQUET E., CHARLIER H., MOCQUOT G., 1966b. La microflore du tube digestif du rat. II. - Dénombrement de différenis genres microbiens dans l'estomac ef l'intestin de rats conventionnels; variations quantitatives individuelles ef en fonction de l'âge. Ann. Inst. Pasteur, 110, 861-876.

RAIBAUD P., DICKINSON A., SACQUET E., CHARLIER H., MOCQUOT G., 1966c. La microflore du tube digestif du rat. IV. - Implantation contrôlée chez le rat gnotobiotique de différents genres microbiens isolés du rat conventionnel. Ann. Inst. Pasfeur, 111, 193-210.

RAIBAUD P., DUCLUZEAU R., MULLER M. C., SACQUET E., 1974. Le taurocholate de sodium, facteur de germination in vitro et in vivo, dans le tube digestif d'animaux gnotoxéniques, pour les spores de certaines bactéries anaérobies strictes isolées de fèces humaines et animales. Ann. Microbiol. Inst. Pasteur, 125 B, 381-391.

RENAULT L., MAIRE C., VAISSAIRE J., LABADIE J., ALBOUY R., 1976. Contribution à l'étude des troubles digestifs des lapereaux en début d'engraissement. 1 er Congr. int. Cunic., Dijon, France, Communic. no 46.

SMITH H. W., 1965a. The development of the flora of the alimentary tract in young animals. J. Path. Bact., 90, 495-513.

SMITH H. W., 1965b. Observations on the flora of the alimentary tract of animals and factors affecting its composition. J. Path. Bact., 89, 95-122.

TROVATELLI L. D., CROCIANI F., PEDINOTTI M., SCARDOVI V., 1974. Bifidobacterium pullorum sp. nov., a new species isolated from chicken feces and a related group of Bifidobacteria isolated from rabbit feces. Arch. Microbiol., 98, 187-198.

VÖRÖS G., 1976. Investigations relating to diseases of the digestive system at weaning rabbits. 1 er Congr. int. Cunic. Dijon, France, Communication no 42.

YALCIN N., CORDIER L., 1976. Sérotypes d'Escherichia coli identifiés à partir de l'entérite mucoïde des lapereaux âgés de moins de six semaines. 1 er Congr. int. Cunic., Dijon, France, Communication $n^{\circ} 45$. 